\title{
New antitumour active platinum compounds containing carboxylate ligands in trans geometry: synthesis, crystal structure and biological activity
}

\author{
Steven van Zutphen, ${ }^{a}$ Elena Pantoja, ${ }^{a}$ Rosario Soriano, ${ }^{a}$ Carlos Soro, ${ }^{a}$ Duncan M. Tooke, ${ }^{b}$ Anthony L. Spek, ${ }^{b}$ \\ Hans den Dulk, ${ }^{a}$ Jaap Brouwer ${ }^{a}$ and Jan Reedijk*a
}

Received 31st August 2005, Accepted 23rd November 2005

First published as an Advance Article on the web 7th December 2005

DOI: $10.1039 / \mathrm{b512357g}$

\begin{abstract}
New asymmetric trans-platinum(II) complexes, composed of an isopropylamine, an azole and two carboxylate leaving groups, are presented. The crystal and molecular structures of one of the complexes has been determined and the cytotoxicity and reactivity with $5^{\prime}$-guanosine monophosphate is reported. The complexes show a reduced reactivity, but no decrease in cytotoxic activity compared to their chloro-counterparts. Furthermore the complexes largely overcome cisplatin resistance, they therefore present an interesting class of antitumour active trans-platinum complexes.
\end{abstract}

\section{Introduction}

Cisplatin and many other platinum drugs are known DNAbinding agents. ${ }^{1}$ The majority of platinum drugs contain two leaving groups, allowing the complexes to react with DNA in a bifunctional manner. In early structure-activity relationship studies both the nature and geometry of these leaving groups was investigated..$^{2-4}$ It was concluded that for antitumour activity platinum complexes must have two labile leaving groups in cis geometry. Compounds with $\mathrm{Cl}^{-}$or $\mathrm{Br}^{-}$leaving groups display mostly good activity, however more stable ligands can also yield active compounds. In fact, the second generation platinum drugs, carboplatin, nedaplatin and oxaliplatin have all exchanged the $\mathrm{Cl}^{-}$ leaving groups of cisplatin for kinetically less labile chelating dicarboxylate or glycolate ligands. ${ }^{5-8}$ As a result patients treated with these compounds suffer from less severe dose-limiting side effects. In more recent years, a number of trans compounds with high antitumour activities in both cisplatin-sensitive and cisplatin-resistant cell lines have been discovered..$^{9-13}$ Although these compounds have not yet entered the clinic, it is not unlikely that their treatment will be obstructed by dose-limiting side effects similar to cisplatin, owing to the nature of the $\mathrm{Cl}^{-}$leaving groups. It has been shown that the chlorides on various trans platinum complexes can be replaced efficiently by acetate ligands. ${ }^{14,15}$ Furthermore, it was recently discovered that trans-diaminedicarboxylate complexes can have greatly increased aqueous solubility compared to their dichloro counterparts. ${ }^{16,17}$ In the current study the influence of the acetate ligand on the reactivity and in vitro cytotoxicity of two recently discovered active trans amine platinum complexes is described in detail, including the crystal and molecular structures of one of them.

\section{Results and discussion}

Synthesis and characterisation

The known, earlier reported active trans-platinum complexes 1 and 2 served as a starting point for the current study. ${ }^{18}$ Their synthesis

${ }^{a}$ Leiden Institute of Chemistry, Gorlaeus Laboratories, Leiden University, P.O. Box 9502, 2300, RA Leiden, The Netherlands.E-mail: reedijk@, chem.leidenuniv.nl; Fax: +3171527 4671; Tel: +31715274459

${ }^{b}$ Crystal and Structural Chemistry, Utrecht University, Padualaan 8, 3584, $\mathrm{CH}$ Utrecht, The Netherlands was based on literature procedures. ${ }^{19}$ These compounds, contain an azole and an isopropylamine ligand trans to one another, and have shown high in vitro activities in both cisplatin sensitive and cisplatin resistant cell lines. ${ }^{18}$ This activity may be related to the fact that these complexes react with DNA in a monofunctional manner, quite unlike platinum complexes with cis geometry. ${ }^{18}$ Using these chloro compounds as starting materials in the synthesis of the target compounds 3 and $\mathbf{4}$, the $\mathrm{Cl}^{-}$ligands have to be exchanged for $\mathrm{OAc}^{-}$(see Scheme 1 for the reactions). Stirring the complexes in aqueous sodium acetate solution over a long period of time was expected to yield the desired products. However, the rate of reaction is rather low, due to the slow hydrolysis of the platinumchloride bond. In order to increase the reaction rate, $\mathrm{Ag}^{+}$ions can be added to the solution. ${ }^{20}$ In this case, the precipitation of $\mathrm{AgCl}$ moves the equilibrium towards the hydrated species, thereby greatly increasing the rate of product formation. Treating the chloro complexes $\mathbf{1}$ and $\mathbf{2}$ with AgOAc yielded the desired complexes $\mathbf{3}$ and $\mathbf{4}$ in a simple overnight reaction. This silver salt was prepared by neutralising acetic acid with $\mathrm{NaOH}$ followed by treatment with $\mathrm{AgNO}_{3}$. Due to the low solubility of this silver salt, best results were obtained by treating the chloro compounds with

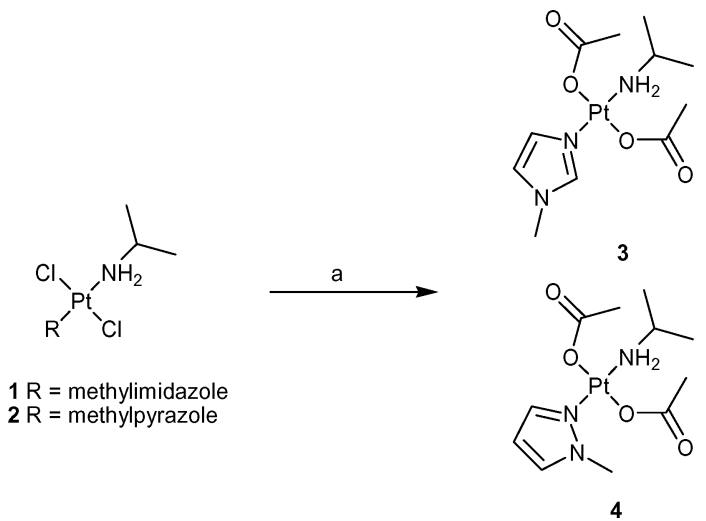

Scheme 1 Synthesis of trans carboxylate complex trans-[Pt(OAc) $)_{2}$ (isopropylamine)( $N$-methylimidazole)] 3 and trans-[Pt(OAc) (isopropylamine $)(N$-methylpyrazole $)] \mathbf{4}$ starting from the chloride precursor $\mathbf{1}$ or 2 respectively. a) $\mathrm{AgOAc}$ in $\mathrm{H}_{2} \mathrm{O}$. 
a small excess of $\mathrm{AgOAc}$ overnight at $40{ }^{\circ} \mathrm{C}$ in water. The platinum carboxylate complexes formed in solution so that they could be separated by filtration from the excess AgOAc, unreacted dichloro complex and $\mathrm{AgCl}$ formed during the reaction. Any silver ions remaining in the solution were reduced by exposing the reaction to light and the reaction mixture was filtered again. Freeze-drying the resultant solution yielded compounds $\mathbf{3}$ and $\mathbf{4}$ in low, but acceptable yield (10-15\%) of high purity. The structural integrity of the complexes was verified using ${ }^{1} \mathrm{H}$ NMR, ${ }^{195} \mathrm{Pt}$ NMR and ESIMS. For complex 3 crystals where obtained by slow evaporation of a methanolic solution of the compound and used in a single crystal X-ray structure determination (Fig. 1). This confirmed the expected square-planar platinum moiety surrounded by the two carboxylate ligands in trans position and the two nitrogen donor ligands trans to one another, together with a single water molecule of crystallisation.

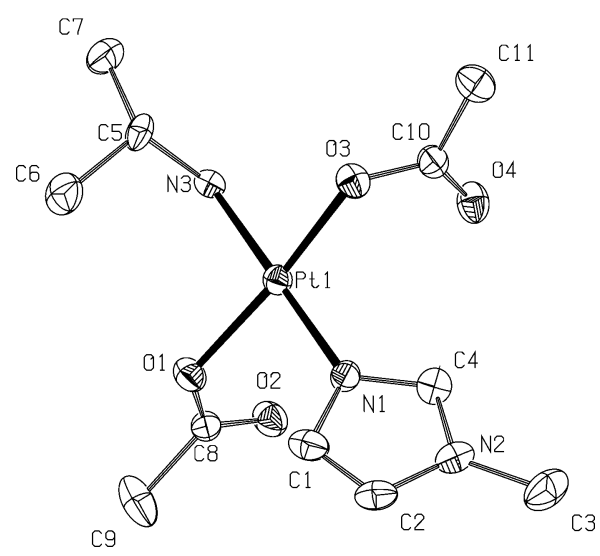

Fig. 1 Displacement ellipsoid plot $(50 \%)$ of trans-[Pt $(\mathrm{OAc})_{2}$ (isopropylamine)( $N$-methylimidazole) 3 3. $\mathrm{H}$ and $\mathrm{H}_{2} \mathrm{O}$ omitted for clarity.

\section{Biological evaluation}

To analyse the compounds' potential as antitumour agents the $\mathrm{IC}_{50}$ values were determined in two L1210 mouse leukaemia cell lines, i.e. one sensitive and one resistant to cisplatin treatment. The results are illustrated in Table 1 . The compounds are moderately active, slightly less active than cisplatin yet more active than carboplatin in the sensitive cell line. Moreover, the complexes largely retain their activity in the L1210R cell line, unlike cisplatin or carboplatin. In fact, with a resistance factor of 1.7 and 1.3 respectively, complexes $\mathbf{3}$ and $\mathbf{4}$ show 10-fold less reduction in activity in the resistant cell line than cisplatin. Although such behaviour may be expected for asymmetric dichloro transplatinum complexes, it is of interest that changing the leaving groups to acetate does not appear to alter the cytotoxic properties

Table $1 \mathrm{IC}_{50}$ values $(\mu \mathrm{M})$ for complexes $\mathbf{3}, \mathbf{4}$, cisplatin and carboplatin in two different cell lines, L1210, L1210R mouse leukemia sensitive and resistant to cisplatin on $72 \mathrm{~h}$ incubation

\begin{tabular}{lll}
\hline Entry & L1210 & L1210R \\
\hline $\mathbf{3}$ & $6.43 \pm 0.71$ & $11.1 \pm 0.34$ \\
$\mathbf{4}$ & $5.98 \pm 0.52$ & $7.86 \pm 0.92$ \\
Cisplatin & $1.73 \pm 0.08$ & $27.5 \pm 0.90$ \\
Carboplatin & $10.2 \pm 1.69$ & $>50$ \\
\hline
\end{tabular}

of the complexes. These data clearly show that these complexes present a promising class of platinum antitumour agents.

To gain insight into the reactivity of the complexes, directly related to the toxicity of platinum complexes, ${ }^{21}$ the reaction of complex 3 with an excess of the nucleobase 5'-guanosine monophosphate (5'GMP) was followed by ${ }^{1} \mathrm{H}$ NMR at physiological temperature in buffered solution and compared to carboplatin (Fig. 2). In this reaction the labile ligands of a platinum complex are replaced by the nucleobase coordinated via the $\mathrm{N} 7$ nitrogen to give a bis-5'GMP platinum adduct. In $0.1 \mathrm{M} \mathrm{NaClO}_{4}$ in $\mathrm{D}_{2} \mathrm{O}$ the bisadduct of cisplatin is known to be formed rapidly and the reaction is complete within $24 \mathrm{~h} .{ }^{22}$ For carboplatin the reaction rate is much slower, but the rate can be increased by adding $50 \mathrm{mM} \mathrm{NaCl}$ to the reaction..$^{23}$ Under these conditions, the same bisadduct is observed after $3 \mathrm{~h}$ of reaction, but it takes 6 days for the reaction to reach completion. In the absence of $\mathrm{NaCl}$ the platinum bis $\left(5^{\prime} \mathrm{GMP}\right)$ adduct of complex $\mathbf{3}$ is detectable only after 4 days of reaction, and after 11 days only $30 \%$ of product is formed. In the presence of $\mathrm{NaCl}$ the bisadduct is detectable after $15 \mathrm{~h}$ and the reaction is complete after 11 days. At this point a ${ }^{195} \mathrm{Pt} \mathrm{NMR}$, showing a single peak at $-2383 \mathrm{ppm}$, was used to confirm the completed formation of the bisadduct. In summary, the carboxylate complexes are kinetically much more inert than either cisplatin or carboplatin. In contrast, compounds $\mathbf{1}$ and $\mathbf{2}$ are known to react with 5'GMP at a rate only slightly lower than cisplatin, and it takes a mere $48 \mathrm{~h}$ for the reaction to reach completion. ${ }^{18}$ It appears therefore that the complexes presented in the current paper are able to retain their cytotoxic activity compared to their chloro-analogues, whilst their reactivity towards DNA nucleobases is reduced significantly.

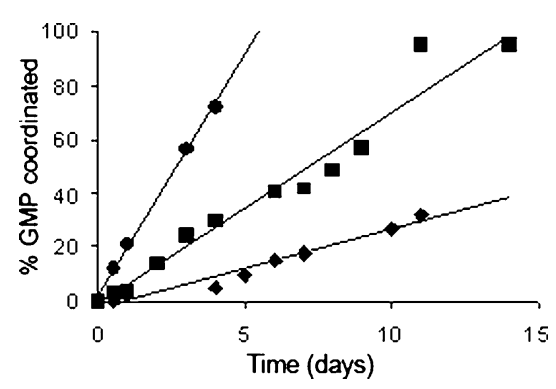

Fig. 2 Graph showing the percentage of 5'GMP coordinated relative to the amount of platinum compound present, illustrating the difference in reaction rate for 3 and carboplatin with or without the addition of $\mathrm{NaCl}$ to the reaction mixture. $\bullet$ : carboplatin $(51 \mathrm{mM} \mathrm{NaCl}), \boldsymbol{\$} \mathbf{3}+5^{\prime} \mathrm{GMP}$ $\left(\mathrm{NaClO}_{4}\right), \mathbf{\square}: \mathbf{3}+5^{\prime} \mathrm{GMP}(51 \mathrm{mM} \mathrm{NaCl})$.

\section{Conclusion}

We have synthesised two representative examples of a group of new platinum complexes for anti-tumour evaluation, based on known active trans-dichloro compounds and simple carboxylate ligands. The biological evaluation shows that these compounds display high cytotoxicity in both cisplatin-sensitive and cisplatin-resistant cell lines, whilst at the same time showing low reactivity in a model reaction with $5^{\prime} \mathrm{GMP}$ monitored by ${ }^{1} \mathrm{H}$ NMR. Their chlorocounterparts show similar cytotoxic activity but a fast reaction with 5'GMP. This fundamental differnce is similar to the difference observed between cisplatin and carboplatin. The main advantage 
of carboplatin over cisplatin is the reduced toxic side-effects in the clinic. The results presented in the current paper may therefore indicate that the asymmetric trans-carboxylate complexes could display high antitumour activity in combination with reduced toxic side effects in vivo, compared to either cisplatin or their chloro-analogues. Current studies with the complexes aim to verify this hypothesis. Furthermore, studies aimed at determining whether our results can be generalised for other known active trans-platinum(II) compounds are ongoing.

\section{Experimental}

All NMR measurements were performed on a $300 \mathrm{MHz}$ Bruker DPX300 spectrometer with a $5 \mathrm{~mm}$ multi-nucleus probe. Temperature was kept constant at $298 \mathrm{~K}$ or $310 \mathrm{~K}$ using a variable temperature unit. ${ }^{1} \mathrm{H}$ and ${ }^{195} \mathrm{Pt}$ chemical shifts were referenced to TSP and $\mathrm{Na}_{2} \mathrm{PtCl}_{4}(\delta=0 \mathrm{ppm})$, respectively. The water signal for spectra measured in $\mathrm{D}_{2} \mathrm{O}$ was minimized using a WATERGATE pulse sequence.

\section{Synthesis of 3}

To trans-[ $\mathrm{PtCl}_{2}$ (isopropylamine)( $N$-methylimidazole)] 1 (20 mg, $49 \mu \mathrm{mol})$ in water $(2 \mathrm{ml})$ was added AgOAc $(147 \mu \mathrm{mol})$. The suspension was stirred overnight in the dark at $40{ }^{\circ} \mathrm{C}$. The suspension was cooled to room temperature, filtered and the solution was exposed to light for $1 \mathrm{~h}$. The resultant suspension was filtered and the solution was freeze-dried to yield complex 3 in $15 \%$ yield. ${ }^{195} \mathrm{Pt}$ NMR $\left(\mathrm{D}_{2} \mathrm{O}\right) \delta(\mathrm{ppm}):-1480 .{ }^{1} \mathrm{H}$ NMR $\left(\mathrm{D}_{2} \mathrm{O}\right)$ $\delta$ (ppm): 1.24 (d, $J=6.43,6 \mathrm{H}, \mathrm{CH}(\mathrm{CH} 3) 2), 1.84$ (s, 3H, CH3acetate), 2.80 (sept, $\left.J=6.68,1 \mathrm{H}, \mathrm{CH}\left(\mathrm{CH}_{3}\right)_{2}\right), 3.67\left(\mathrm{~s}, 1 \mathrm{H}, \mathrm{NCH}_{3}\right)$, $6.74(\mathrm{~d}, J=2.63,1 \mathrm{H}, \mathrm{NCH}), 7.04$ (d, $J=2.63,1 \mathrm{H}, \mathrm{NCH}), 7.53$ (s, 1H, NCHN). ESI-MS: $m / z: 454[\mathrm{M}+\mathrm{H}]^{+}, 477[\mathrm{M}+\mathrm{Na}]^{+}$. IR $\left(\mathrm{cm}^{-1}\right): 1594 v(\mathrm{C}=\mathrm{O})$.

\section{Synthesis of 4}

As for 3 where 1 was replaced by trans- $\left[\mathrm{PtCl}_{2}\right.$ (isopropylamine) $(N$ methylpyrazole)] 2. Yield $12 \% .{ }^{195} \mathrm{Pt} \mathrm{NMR}\left(\mathrm{D}_{2} \mathrm{O}\right) \delta(\mathrm{ppm}):-1471$. ${ }^{1} \mathrm{H}$ NMR $\left(\mathrm{D}_{2} \mathrm{O}\right) \delta(\mathrm{ppm}): 1.41\left(\mathrm{~d}, J=6.43,6 \mathrm{H}, \mathrm{CH}\left(\mathrm{CH}_{3}\right)_{2}\right), 2.14$ (s, 3H, $\mathrm{CH}_{3}$-acetate), 2.97 (sept, $\left.J=6.68,1 \mathrm{H}, \mathrm{CH}\left(\mathrm{CH}_{3}\right)_{2}\right), 3.85$ $\left(\mathrm{s}, 1 \mathrm{H}, \mathrm{NCH}_{3}\right), 6.94(\mathrm{t}, J=1.67,1 \mathrm{H}, \mathrm{NCH}), 7.25(\mathrm{~d}, J=1.39$ $1 \mathrm{H}, \mathrm{CHCHCH}), 7.71$ (d, $J=1.54,1 \mathrm{H}, \mathrm{NCH})$. ESI-MS: $m / z: 477$ $[\mathrm{M}+\mathrm{Na}]^{+}$. IR $\left(\mathrm{cm}^{-1}\right): 1594 v(\mathrm{C}=\mathrm{O})$.

\section{5'GMP reactions}

A four-fold excess of 5'GMP was reacted with complex 3 and carboplatin at $310 \mathrm{~K}$ in $0.1 \mathrm{M} \mathrm{NaClO}_{4}$ in $\mathrm{D}_{2} \mathrm{O}$ or $0.1 \mathrm{M} \mathrm{NaClO}_{4}$ and $50 \mathrm{mM} \mathrm{NaCl}$ in $\mathrm{D}_{2} \mathrm{O}$. All reactions were monitored by recording a ${ }^{1} \mathrm{H}$ NMR spectrum every $30 \mathrm{~min}$ for $16 \mathrm{~h}$ then every $24 \mathrm{~h}$ until no further changes were observed.

\section{Growth inhibition assays in L1210 and L1210R}

The mouse leukaemia cell lines were a gift from Dr J. M. Pérez (Universidad Autónoma de Madrid, Spain). Growth inhibition by the complexes $\mathbf{3}, \mathbf{4}$, cisplatin and carboplatin was determined using an MTT-based assay. ${ }^{24}$
Table 2 Crystallographic data for complex 3

$\begin{array}{ll}\text { Chemical formula } & \mathrm{PtC}_{11} \mathrm{H}_{21} \mathrm{~N}_{3} \mathrm{O}_{4} \cdot \mathrm{H}_{2} \mathrm{O} \\ \text { Formula weight } & 472.41 \\ \text { Crystal system } & \text { Monoclinic } \\ \text { Space group } & P 2_{1} / c \\ a / \AA & 9.8064(6) \\ b / \AA & 12.5128(7) \\ c / \AA & 15.6712(11) \\ a /^{\circ} & 90 \\ \beta /{ }^{\circ} & 123.406(5) \\ \gamma /{ }^{\circ} & 90 \\ V / \AA^{3} & 1605.3(2) \\ Z & 4 \\ \rho_{\text {calc }} / \mathrm{g}^{-1}{ }^{-3} & 1.955 \\ \mu / \mathrm{mm}^{-1} & 8.762 \\ \text { Transmission } & 0.34-0.5 \\ \text { Crystal color } & \mathrm{Colourless} \\ \text { Crystal size/mm } & 0.14 \times 0.08 \times 0.08 \\ \text { No. refl. measured } & 25395 \\ \text { No. unique refl. } & 3675 \\ \text { No. parameters } & 194 \\ R 1 \text { (all refl.) } & 0.0604 \\ R 1 \text { (obs. refl.) } & 0.0287 \\ w R 2 \text { (all refl.) } & 0.0519 \\ w R 2 \text { (obs. refl.) } & 0.0459 \\ \text { (sin } \theta / \lambda)_{\text {max }} / \AA^{-1} & 0.65 \\ R_{\text {int }} & 0.03 \\ \text { GoF(goodness of fit) } & 1.01 \\ \text { Residual electron density/e } \AA^{-3} & -1.22 / 0.81 \\ & \end{array}$

\section{X-Ray crystal structure determination}

Nonius KappaCCD diffractometer, rotating anode, MoK $\alpha$ radiation (graphite monocromator), 150(2) K. See Table 2 for crystallographic data. Multi-scan absorption correction applied using SADABS. ${ }^{25}$ Structure solved with DIRDIF99926 and refined with SHELXL-97. ${ }^{27}$ Drawings, structure calculations, and checking for additional symmetry performed with PLATON. ${ }^{28}$ Non-hydrogen atoms refined freely with anisotropic displacement parameters. $\mathrm{H}(5 \mathrm{~A})$ and $\mathrm{H} 5$ (B) of the water molecule were located in a difference map and freely refined with isotropic displacement parameters. All other $\mathrm{H}$ atoms in geometrically idealized positions $[d(\mathrm{C}-\mathrm{H})=$ 0.98 for methyl $\mathrm{H}$ and 0.95 for other $\mathrm{H}$ ] and constrained to ride on parent atoms, $U_{\text {iso }}(\mathrm{H})=1.5 U_{\text {eq }}(\mathrm{C})$ for methyl $\mathrm{H}$ and $U_{\text {iso }}(\mathrm{H})=$ $1.2 U_{\text {eq }}(\mathrm{C})$ for all other $\mathrm{H}$.

CCDC reference number 279701.

For crystallographic data in CIF or other electronic format see DOI: $10.1039 / \mathrm{b} 512357 \mathrm{~g}$

\section{Acknowledgements}

This research was supported by the Council for Chemical Sciences of the Netherlands Organisation for Scientific Research (CWNWO). Support and sponsorship by COST Action D20 is kindly acknowledged. The authors thank Johnson \& Matthey (Reading, $\mathrm{UK}$ ) for their generous loan of $\mathrm{K}_{2} \mathrm{PtCl}_{4}$.

\section{References}

1 J. Reedijk, Proc. Natl. Acad. Sci. U. S. A., 2003, 100, 3611.

2 M. J. Cleare, P. C. Hydes, B. W. Malerbi and D. M. Watkins, Biochimie, 1978, 60, 835.

3 T. A. Connors, M. J. Cleare and K. R. Harrap, Nature (London), 1979, 63, 1499.

4 J. D. Hoeschele, Abstr. Pap. Am. Chem. Soc., 1974, 16. 
5 A. H. Calvert, S. J. Harland, D. R. Newell, Z. H. Siddik, A. C. Jones, T. J. McElwain, S. Raju, E. Wiltshaw, I. E. Smith, J. M. Baker, M. J. Peckham and K. R. Harrap, Cancer Chemother. Pharmacol., 1982, 9, 140.

6 S. G. Allan and J. F. Smyth, Br. J. Cancer, 1986, 53, 355.

7 H. Akaza, M. Togashi, Y. Nishio, T. Miki, T. Kotake, Y. Matsumura, O. Yoshida and Y. Aso, Cancer Chemother. Pharmacol., 1992, 31, 187.

8 http://www.fda.gov/bbs/topics/NEWS/2002/NEW00825.html.

9 S. Radulovic, Z. Tesic and S. Manic, Curr. Med. Chem., 2002, 9, 1611.

10 J. Kasparkva, O. Novakova, V. Marini, Y. Najajreh, D. Gibson, J. M. Perez and V. Brabec, J. Biol. Chem., 2003, 278, 47516.

11 J. Kasparkova, V. Marini, Y. Najajreh, D. Gibson and V. Brabec, Biochemistry, 2003, 42, 6312.

12 E. S. F. Ma, W. D. Bates, A. Edmunds, L. R. Kelland, T. Fojo and N. Farrell, J. Med. Chem., 2005, 48, 5651.

13 Y. Najajreh, J. M. Perez, C. Navarro-Ranninger and D. Gibson, J. Med. Chem., 2002, 45, 5189.

14 M. Basato, A. Cardinale, S. Salvo, C. Tubaro and F. Benetollo, Inorg Chim. Acta, 2005, 358, 659.

15 M. Basato, A. Biffis, G. Martinati, C. Tubaro, A. Venzo, P. Ganis and F. Benetollo, Inorg. Chim. Acta, 2003, 355, 399.

16 S. M. O. Quintal, Y. Qu, A. G. Quiroga, J. Moniodis, H. I. S. Nogueira and N. Farrell, Inorg. Chem., 2005, 44, 5247.
17 E. S. F. Ma, W. D. Bates, A. Edmunds, L. R. Kelland, T. Fojo and N. Farrell, J. Med. Chem., 2005, 48, 5651.

18 E. Pantoja, Ph.D. Thesis, Leiden University, 2005.

19 L. R. Kelland, C. F. J. Barnard, I. G. Evans, B. A. Murrer, B. R. C. Theobald, S. B. Wyer, P. M. Goddard, M. Jones, M. Valenti, A. Bryant, P. M. Rogers and K. R. Harrap, J. Med. Chem., 1995, 38, 3016.

20 S. van Zutphen, M. S. Robillard, G. A. van der Marel, H. S. Overkleeft, H. den Dulk, J. Brouwer and J. Reedijk, Chem. Commun., 2003, 634.

21 T. W. Hambley, Coord. Chem. Rev., 1997, 166, 181.

22 G. Y. H. Chu, S. Mansy, R. E. Duncan and R. S. Tobias, J. Am. Chem. Soc., 1978, 100, 593.

23 U. Frey, J. D. Ranford and P. J. Sadler, Inorg. Chem., 1993, 32, 1333.

24 S. van Zutphen, E. A. Stone, S. H. van Rijt, M. S. Robillard, G. A. van der Marel, H. S. Overkleeft, H. den Dulk, J. Brouwer and J. Reedijk, J. Inorg. Biochem., 2005, 99, 2032.

25 G. M. Sheldrick, in SADABS, Program for Absorption Correction, Bruker AXS, Karlsruhr, Germany, 2004.

26 P. T. Beurskens, G. Beurskens, R. de Gelder, S. Garcia-Granda, O. Gould, R. Israel and J. M. M. Smits, The DIRDIF-99 program system, Crystallography Laboratory, University of Nijmegen, The Netherlands, 1999.

27 G. M. Sheldrick, in Program for crystal structure refinement, University of Göttingen, Germany, 1997.

28 A. L. Spek, J. Appl. Crystallogr., 2003, 36, 7. 